\title{
Ugor-Török Háború as Invented Intellectual Tradition in Hungarian Nationalism
}

\author{
M. V. Kyrchanov
}

For citation: Kyrchanov M.V. Ugor-Török Háború as Invented Intellectual Tradition in Hungarian Nationalism. Vestnik of Saint Petersburg University. History, 2018, vol. 63, issue 2, pp. 463-478. https:// doi.org/10.21638/11701/spbu02.2018.209

The author analyses the Türkic myth in Hungarian national identity. Hungarian Turkism emerged in the $19^{\text {th }}$ century and developed as part of ethnic and political nationalisms in the $20^{\text {th }}$ century. Propaganda of the ideas of Turkism became the reason for "Ugric-Turkic war" several waves of intellectual discussions and debates of Hungarian nationalists about the primacy of Ugrism or Turkism as the basis for Hungarian national and ethnic identities. Hungarian Turkism became a part of the intellectual history of Hungary and the invented intellectual and cultural tradition. Representatives of early Hungarian Turkism were romantic nationalists who idealised ancient Turks as possible ancestors of Hungarians. The ideologists of Hungarian Turkism in the early $20^{\text {th }}$ century and the era of the First World War were pragmatic nationalist politicians who hoped to benefit from cooperation with the Ottoman Empire. The ideas of Turkism competed with the Magyar myths in Hungarian ethnic nationalism. Turkish nationalists and ideologists of Pan-Turkism supported the theorists of Hungarian Turkism. The founding fathers of the Turkic myth developed radical ethnic versions of identity and simultaneously stimulated the emergence of a national tradition of Oriental Turkic studies. Turanism as the ideology of Hungarian nationalism failed to realise its potential in competition with the ethnic and political trends of Magyarism. The ideas of Turanism could not effectively resist the modernization and consolidation potential of Hungarian political nationalism. The ideas of Hungarian statehood supplanted the values of Turanism. The political collapse of the Ottoman Empire as the greatest Turkic state also contributed to the fall of the popularity of Turanism. Turanism transformed in the studies of the history of Hungary during the period of Turkish rule, and the history of cultural, linguistic and ethnic contacts in contemporary Hungarian historiography. Non-academic historiography continues to develop the political mythology of Turanism.

Keywords: Hungary, nationalism, intellectuals, Ugrism, Turkism, Turanism, Magyarism.

\section{Угорско-тюркская война как изобретенная интеллектуальная традиция венгерского национализма}

\section{М. В. Кирчанов}

Для цитирования: Kyrchanov M. V. Ugor-Török Háború as Invented Intellectual Tradition in Hungarian Nationalism // Вестник Санкт-Петербургского университета. История. 2018. Т. 63. Вып. 2. C. 463-478. https://doi.org/10.21638/11701/spbu02.2018.209

Maksym V. Kyrchanov - Doctor in History, Associate Professor, Voronezh State University, 16, Pushkinskaia, Voronezh, 394036, Russian Federation; maksymkyrchanoff@gmail.com

Максим Валерьевич Кирчанов - д-р ист. наук, доц., Воронежский государственный университет, Российская Федерация, 394036, Воронеж, Пушкинская, 16; maksymkyrchanoff@gmail.com

(C) Санкт-Петербургский государственный университет, 2018 
Автор анализирует тюркский миф в венгерской национальной идентичности. Венгерский тюркизм возник в XIX в. и развивался как часть этнического и политического национализма в XX в. Пропаганда идей тюркизма стала поводом для угорско-тюркской войны - нескольких волн интеллектуальных дискуссий и дебатов венгерских националистов о примате угризма или тюркизма как основ венгерской национальной и этнической идентичности. Венгерский тюркизм стал частью интеллектуальной истории Венгрии и изобретенной интеллектуальной и культурной традицией. Представители раннего венгерского тюркизма были романтиками и националистами, идеализировавшими древних тюрок как возможных предков венгров. Идеологи венгерского тюркизма в начале XX в. и в годы Первой мировой войны были прагматическими националистическими политиками, которые надеялись получить выгоды от сотрудничества с Османской империей. Идеи тюркизма конкурировали с мадьярскими мифами в венгерском этническом национализме. Теоретики венгерского тюркизма были поддержаны турецкими националистами и идеологами пантюркизма. Популяризаторы тюркского мифа одновременно развивали радикальные этнизированные версии идентичности и стимулировали возникновение национальной традиции востоковедных тюркских исследований. Туранизм в идеологии венгерского национализма, с одной стороны, не смог реализовать свой потенциал в конкуренции с этническими и политическими течениями мадьяризма. С другой стороны, идеи туранизма не смогли эффективно противостоять модернизационному и консолидационному потенциалу венгерского политического национализма. Идеи венгерской государственности вытеснили ценности туранизма. Политический крах Османской империи как крупнейшего тюркского государства также содействовал падению популярности туранизма. Туранизм в современной венгерской историографии трансформировался в изучение истории Венгрии периода турецкого владычества и истории культурных, лингвистических и этнических контактов. Неакадемическая историография продолжает развивать политическую мифологию туранизма.

Ключевые слова: Венгрия, национализм, интеллектуалы, угризм, тюркизм, туранизм, мадьяризм.

The formulation of the problem. Nationalists have contradictory relationships with history. Historians can be among nationalists because they do a lot for the emergence, liberation, and progress of nations they belong to, or just dream that these nations will become recognized members of the modern world, which mainly consists of nations and nation-states. Nationalist perceptions of history are radically different from the academic ones. Historians and intellectuals of the nationalist orientations do not face restrictions and regulations of the formalized rules of academic ethics. Nationalists openly use history for their political purposes, although historians can also be nationalists and correlate history with the political needs of the nation or its political classes. Nationalisms of the $19^{\text {th }}$ and $20^{\text {th }}$ centuries had complex relationships with the history, but nationalists inspired the developments of academic historiographies. They provided oppressed groups and communities, which were ambitious enough to transform into political nation-states, with national histories.

Academic historiography and nationalism of the oppressed groups evolved simultaneously because they became the inevitable and forced allies in the processes of social transformations and cultural mutations of traditional peasant communities into modern nations. Early national historiographies and nationalism concerned achieving the same political goals. If political nationalists insisted that the imagined and invented nation need 
political freedom, independence, and the nation state, the historians of nationalist orientation provided the groups they aimed at with glorious past and great national history. The legitimization of the ideas of political freedom, sovereignty, and independence were impossible without the invention and imagination of great ancestors, who symbolised political and state traditions of the heterogenous communities in question. The collective awareness and understanding that historical state and great ancestors had utmost importance for the actual politics and ideological struggle stimulated European nationalists of the $19^{\text {th }}$ and $20^{\text {th }}$ centuries to invent and imagine ancestral ethnic groups and states. The collective desires to provide the nation with great ancestors inspired nationalists to impose modern ethnicities and identities on various communities that had nothing in common with the nations of the $19^{\text {th }}$ century.

The purpose and tasks of the article, or what this article is not about? The author attempts to analyze intellectual strategies, political practices of nationalists, their collective and individual attempts to nationalize historical groups of different ethnic descents. Nationalists prefer to imagine them as ancestors of their modern nations in spite the fact that they had nothing in common with contemporary groups genetically and ethnically. The author, on the one hand, will analyze how Hungarian nationalists attempt to integrate the Turks in the grand narratives of national histories. These non-academic strategies actualize the common trends of ethnicization of history, in general, and local practices of nationalist inventions, in particular. The author will explore how nationalist historians and other intellectuals imagine, invent and construct symbolic links between the nations they belong to, and different ancient and medieval ethnic groups and communities. The author will examine the transplantations of modern national identities in the history of different groups because the nationalists prefer to actualize connections between historical communities and their nations, find ancient elements in the modern nations and provide their historical predecessors with contemporary ethnicities and identities.

Methodological and theoretical backgrounds. This text is an attempt to analyse how nationalists actualize the role of history and historical imaginations in the process of legitimation of the political processes. Nationalist historiography is too extensive and virtually boundless. The author understands that a significant part of the texts and ideas, which he analyses in this article, has nothing in common with academic historiography. The rejection, denial and ignoring of these texts by representatives of academic historiography are understandable and justifiable, but the author attempts at exploring them in terms of their instrumental role in the development and progress of political nationalism and ideas of the nation state. The author considers that instrumentalist theory of nationalism as a special case of Eric Hobsbawm's and Terence Ranger's ${ }^{1}$ modernism and constructivism can form the methodological basis for the analysis of practices and historical manipulations nationalists used for their political needs.

The author presumes that the methodological instrumentarium of intellectual history and the history of ideas is also applicable to studies of the basic trajectories of evolution and the development of Hungarian Turanism. Nationalism stimulated and inspired different forms of political and cultural imagination and became an important determining factor in the transformation of identities and collective representations of the past. Nationalists' aspirations influenced historiography, and nationalism as a romantic ideology

\footnotetext{
1 The Invention of Tradition / eds E. Hobsbawm, T. Ranger. Cambridge, 1983.
} 
or political program defined the main vectors, trajectories and developments of national historiographies. Nationalism assisted in ideologisation and politicisation of academic historical studies and inspired transformation of the history into a predetermined invented tradition that legitimised existence of the nation and its nation-state. The transformations of nation-states into the main actors of historical processes were impossible without the nationalist manipulations, speculations and the invention of political state myth based on the idea of a succession of different forms of state because its political and intellectual elites sought to monopolise various historical states and confirm their exclusive rights to its history.

Nationalist manipulations with history attempt to legitimise political identity and connections with historical ancestors simultaneously. Historicisation of states and political nations that existed in the past is not a consequence of the nationalistic historical speculations solely. The author believes that nationalism as one of the rational political ideologies and its theorists use history to achieve their specific political objectives, advantages, and utilitarian benefits. Historicization of national identity and its further transformation in the invented tradition actualize political components in the ideology of nationalism. Nationalistic historical imagination turns the state into an invented tradition and the main actor of historical processes. The attempts of nationalists to use history actualize political utility and inherent utility of history as politicized and ideologized forms of knowledge. Nationalist manipulations with history are situational and nationalists prefer to use history in political situations when they mobilize the masses for their political and ethnic needs. These intellectual tactics and strategies legitimise transplantations of modern identities and ethnicities in the past and provide nationalists with the opportunities to imagine political and ethnic communities as their "national" and "own". Some intellectuals historicise predecessors radically in spite of the fact that they lived in the world where nations as political actors and nation-states as modern political institutions were absent.

Historical revisionism and nationalism. Nationalist attempts to integrate historical forms of statehood in the national versions of history constitute nationalist discourse and ensure the reproduction of national and political identities. These practices became forms of historical revisionism, an extremely complex phenomenon in the modern historiography from a structural viewpoint. Traditionally, Russian historiography perceives revisionism and any attempts to propose new explanations of the mythologized and ideologized historical facts negatively. American historiography, in particular, and Western revisionist historiography, in general, perceives revisionism differently. James McPherson, the President of the American Historical Association, stated in 2003: "revision is the lifeblood of historical scholarship. History is a continuing dialogue between the present and the past. Interpretations of the past are subject to change in response to new evidence, new questions asked of the evidence, new perspectives gained by the passage of time. There is no single, eternal, and immutable 'truth' about past events and their meaning. The unending quest of historians for understanding the past - that is, 'revisionism' - is what makes history vital and meaningful"'.

The intellectual overcoming of historical and chronological failures was among the most important tasks of historians in nationalising societies. State myth became an ef-

${ }^{2}$ McPherson J. Revisionist Historians // Perspectives on History. The News magazine of American Historical Association. 2003. Vol.41, N 6 (September). URL: https://www.historians.org/publications-and-directories/perspectives-on-history/september-2003/revisionist-historians (accessed 12.02.2017) 
fective and influential instrument in the hands of nationalists for the political and social mobilisation of potential citizens of the nation that did not have their own state, but whose political elites had stable political sentiments and ideological representations about fundamental importance and values of the state. Historians, nationalists and intellectuals used a variety of cultural and social tactics, practices and strategies for the nationalisation of various historical states and their integration into the emerging canon of the national myth of the political, state and ethnic continuities and consistencies. Nationalist historians boldly and decisively exported modern ethnicities and identities as invented traditions in chronologically distant past. The imposing of collective modern concepts of national identity became commonplace in the nationalist strategies of imagination and invention of the past. Historians who participated in the development of nationalism, nations and states they dreamed of, did not face serious methodological and theoretical problems in the nationalisation of the early feudal medieval statehoods. They simply and radically declared their rights to use medieval states as imagined historical precursors of ethnic groups and political nations they belonged to.

The origins and ideological roots of nationalist manipulations with history as a form of historical revisionism can be extremely diverse. On the one hand, the unequal political, ethnic and social statuses stimulate and inspire radical nationalists to reject, deny, revise, and rewrite historical narratives proposed by historians and intellectuals of the dominating political, ethnic or linguistic majorities. This form of historical revisionism, in general, is politically progressive and positive because it stimulates the development, rise, and progress of new national historiographies. Most of the modern national historiographies of independent countries in Central, Eastern, and Balkan Europe started as politically motivated and ideologically inspired forms of historical revisionism intertwined with the political ambitions of the leaders of the nationalist movements. European nationalists rejected the historical schemes of the dominant national groups because active nationalist movements inspired new forms of history writing. The emergence of new nation-states on European political and mental maps stimulated and legitimized processes of a radical revision of history, its nationalization, invention and imagination of the new historical narratives. Nationalists used the grand narratives for legitimation of the political sovereignty and further development of the national identities of nations they belonged to.

Chronologically the positive impact of historical revisionism was very short because the progress of the national statehood, the strengthening of sovereignty and political freedoms, the development of academic institutions, the formation of the national traditions of history writing and its teaching in secondary schools and universities contributed to preservation of historical discourse. This historical discourse can be different, and it can vary from moderate nationalism to the priority of social, political or economic motives and explanations. If the first nationalists were radical revisionists and consistent deniers of historical theories and concepts of the dominant majority, their historiographical heirs piously believed in them as the founding fathers of the nation, but they used academic methods and approaches in their attempts to write the national history. If the early national historiography developed as radically nationalist, its later heirs became extremely conservative and academic.

The second form of revisionism occurs in societies where the national historiography became academic, marginalized nationalism and deprived it of its status of the universal language of historical discipline. Radical ethnic nationalist and marginalized intellectuals 
inspire historical revisionism in these societies. The tactics and strategies of this form of historical revisionism are extremely diverse, but nationalist-minded historians and other intellectuals prefer to imagine and reinvent state and political continuities between the nations they belong to and the states they live in, and their distant historical ethnic and political predecessors. This form of revisionism, in contrast to radical historical revisionism of an active era of national liberation movements, is marginal because modern revisionism offers non-academic approaches, from the viewpoint of the formalized historiography. Revisionists, unlike their nationalist predecessors, use history to prove that the nation they belong to is the most ancient in the world, or the state they live in has always existed, and its political traditions are continuous and consistent.

"Ugor-török háború" in intellectual debates of Hungarian nationalists. Hungarian intellectuals developed ideas of the Turkic origin of the Hungarians under German cultural influence. Friedrich Max Müller (1823-1900) ${ }^{3}$ localized the Hungarians among the Turanian peoples in his typology of languages. Hungarian nationalists realized the potential of Turkism rather quickly and began to seek, prove and justify the Hungarian-Turkish successions and continuities too actively. "Turáni Társaság"4 , or Turanian Society, was founded in 1910 and became the intellectual centre and informal think-tank for the Hungarian intellectuals of Turanist orientation. "Turánizmus" or "uráni gondola" was an attempt to radically revise the idea of the Finno-Ugrian ${ }^{6}$ origin of the Hungarians and provide Hungarian historical nation with the glorious, great and visible ancestors with traditions of independent statehood.

Cooperation of Hungarian intellectuals with their Turkish colleagues ${ }^{7}$ stimulated and inspired their attempts to locate the imagined Magyar nation within the Turkic ones. As for Turkish intellectuals ${ }^{8}$, they were also interested in the tactics and strategies Hungarian nationalists used for the invention of their non-Ugrian identity, with Turkic roots. Sándor Csoma de Körös ${ }^{9}$, Hungarian traveler and one of the founding fathers of the national

${ }^{3}$ Müller Fr. The languages of the seat of war in the East. With a survey of the three families of language, Semitic, Arian and Turanian. London, 1855.

4 Ablonczy B. "Lándzsahegy", néprokonság, small talk: Turanizmus és keleti gondolat a két világháború közötti magyar külpolitikai gondolkodásban // Magyar külpolitikai gondolkodás a 20. században (A VI. Hungarológiai Kongresszus, Debrecen, 2006. augusztus 22-26, szimpóziumának anyaga) / sz. P. Pritz, B. Sipos, M.Zeidler. Budapest, 2006. Ol. 60-73.

5 Schmidt J. Turánizmus // Nyugat. 1925. N 20. P. 137-200; Takács Felvinczi Z. Turánizmus // Nyugat. 1916. N.1. URL: http://epa.oszk.hu/00000/00022/nyugat.htm (accessed 12.02.2017); Sándor K. Nemzet és történelem. Galamus, 2010, december 24. URL: http://www.galamus.hu/index.php?option=com_content\&view=article\&id=44796:nemzet-es-toertenelem-44125\&catid=68\&Itemid=133 (accessed 12.02.2017); Farkas I. A magyar turanizmus török kapcsolatai // Valóság. 2007. 50. évf. 6. sz. Ol. 31-48.

${ }^{6}$ Kaplinski J. Estonians, Finns, Hungarians, Turks and Mongols. An Essay on Language, Hungarian Review. 2011. Vol.2, N 2. URL: http://www.hungarianreview.com/print/estonians_finns_hungarians_ turks_and_mongols (accessed 12.02.2017)

7 Kessler J. Turanism and Pan-Turanism in Hungary, 1890-1945. Berkeley, 1967; Önen N. Turanci hareketler: Macaristan ve Türkiye (1910-1944). Doktora tezi. Ankara, 2003; Oguz A. The Interplay between Turkish and Hungarian Nationalism: Ottoman Pan-Turkism and Hungarian Turanism (1890-1918). A Thesis Submitted to the Graduate School of Social Sciences of the Middle East Technical University. Middle East Technical University, 2005.

8 Aibert B. N. Macaristan’in Turanilikteki Rolü // Türk Yurdu. 1914. Vol. VI, N 4 (April). Ol. 270-274; Akçura Y. Türkçülük // Türk Yili. Istanbul, 1928. Ol. 287-455.

9 Duka Th. Life and Works of Alexander Csoma De Körös: a Biography Compiled Chiefly from Hitherto Unpublished Data. With a Brief Notice of Each of his Unpublished Works and Essays, as well as of his still Extant Manuscripts. London, 1885; Mukerjee H. Hermit-hero from Hungary, Alexander Csoma de 
Orientalism, believed that the Hungarians were relatives of Uighurs who speak one of the Turkic languages ${ }^{10}$. Vámbéry Ármin ${ }^{11}$, another Hungarian Orientalist, looked for the ethnic origins of the Hungarians among the Turkic peoples so actively that he attempted to proclaim them one of the Turkic ethnic groups. János Arany ${ }^{12}$ supported the ideas of Vámbéry Ármin but preferred to develop a cultural and poetic paradigm of Turanism, idealizing and glorifying the imagined Turkic ancestors of the Hungarians.

Ferenc Aurél Pulszky ${ }^{13}$, Hungarian nationalist journalist and political activist, sought to politicise the ideas of Turanism in Hungarian nationalism, while Sándor Márki ${ }^{14}$ was too ambitiously found common ethnic features in the history and developments of European Hungarians and the Turkic peoples of the Russian Empire. Ethnographic Studies of Sándor Márki, another ideologue of Turanism, combined empathies and sympathies to the oppressed ethnic minorities of Russia, and he, as a nationalist, maneuvered between the values of nation and ideas of class, ethnic myths of the imagined solidarity and problems of social liberation. Vilmos Pröhle ${ }^{15}$ also popularized Orientalism in Hungary and encouraged speculations about the possible identity of the Hungarians as Turan nation. Gyula Sebestyén's ideas were more speculative because he truly believed in the Turkic identity of the Hungarians, invented the Turkic elements in the Hungarian folklore and stated numerous similarities between Runes, used by ancient ancestors of the Hungarians and Turks ${ }^{16}$. József Huszka ${ }^{17}$, another Hungarian nationalist, actively developed Turanism as the invented tradition of the imagined Turkic-Hungarian historical continuities and parallels in folk and traditional cultures.

The emergence and further progress of Hungarian Turanism provoked and initiated debates among intellectuals who believed in Turkic or Finno-Ugrian roots and origins of the Hungarians. The controversies and intellectual wars between Ugristts and Turanists stimulated concerns and excitements of the political elites of the Habsburg Empire because they accepted Turanism as an intellectual form of Hungarian ethnic nationalism and an incentive for the political crisis in the empire and stimulus for regional separatism simultaneously. The supporters of the Austro-Hungarian unionism criticized Turanism and became the founders of ethnic trends in Hungarian nationalism, but Turanism ${ }^{18}$ as a political ideology, cultural strategy, and the invented tradition was popular enough among intellectuals and evolved in the compromise form of nationalism, which actualized elements of romanticized Turanism and ideas of ethnic Magyarism.

Koros, the Great Tibetologist. New Delhi, 1981; Le Calloch'B. Alexandre Csoma de Körös // Revue de l'histoire des religions. 1985. N 4. Ol. 353-388.

${ }^{10}$ Csoma Körös A. de. Collected Works. Reproduce editia din 1834. In Calcutta, Baptist Mission Press; 4 vols. Budapest, 1984.

11 Vámbéry Á. A keleti török nyelvről. Pest, 1868; Vámbéry Á. Közép-ázsiai utazás [Central Asian travel]. Pest, 1865; Vámbéry Á. Küzdelmeim. Budapest, 1905.

12 Arany J. Haraszti, Gyula, 1858-1921. Budapest, 1912; Arany J. Válogatott balladái. Budapest, 1917.

13 Pulszky F. Magyarország archaeologiája II. Budapest, 2010.

14 Sándor M. Az ó- és középkor története. Budapest, 1910.

15 Pröhle V. Rendszeres oszmán-török nyelvtan. Pozsony, 1899; Pröhle V. Napkeletről. Budapest, 1922.

16 Sebestyén G. A magyar rovásirás hiteles emlékei. Budapest, 1915.

17 Huszka J. A magyar turáni ornamentika története. Budapest, 1996.

18 Arnakis G. Turanism: An Aspect of Turkish Nationalism // Balkan Studies. 1960. Vol. 1, N 1. Ol. 1932; Demirkan T. Macar Turancilari. Istanbul, 2000; Kiss A. Magyar Kelet-politika a rokonság jegyében — az őstörténet, mint társadalom- és gazdaságpolitikai tényező 100 éve és ma. Budapest, 2015. 
The controversies between Ugrists ${ }^{19}$ and Turanists ${ }^{20}$ inspired intellectual debates known as "ugor-török háború" 21 and facilitated the fragmentation of the Hungarian nationalist discourse: Finno-Ugrism ${ }^{22}$ transformed into ethnic nationalism and Turanism gradually became the basis for the development of Hungarian academic Orientalism. Despite the significant role of ethnic nationalism, the romantic myth about anti-Turkish resistance, absolutization of the language as subjective factor of blood, idealization of Magyar ethnicity, Hungarian intellectuals were active in their studies of Turkish history ${ }^{23}$ that actualized the ideas of Turanism and symbolic Hungarian membership in the Turkic world. Hungarian Turanism developed as several intellectual trends that coexisted in academic and political forms. Hungarian mass media periodically actualized problems of Turanism ${ }^{24}$, but Turanist rhetoric from romantic nationalism transformed into in pseudo-academic manipulations with history from.

Turanism is still among pivotal topics for the non-academic or semi-academic speculations and reflections ${ }^{25}$ about the ethnic roots of the Hungarians. Turanism has lost its political mobilization potential because the civil and the ethnic Hungarian nationalisms in their classic ideological forms have become more adaptable and attractive. The ideas

19 Vaas Th. Hõimuküsimus ja turanism // Üliõpilasleht. 1925. N 6. Ol. 127-128; Sööt K. Észt-magyar müvészek rokonbarátsági érintkezése // Turán. 1932. N 1-4. Ol. 15-17; Virányi E. A finn-ugor néprokonság eszméje az irodalomban // Turán. 1935. N 1-4. Ol. 15-21; Virányi E. Kultuurajaloolised kokkupuuted Eesti ja Ungari vahel // Eesti Hõim. 1928. N 2. L. 97-109; Wilde E. Muljed Ungarist ja ungarlasist // Eesti Hõim. 1928. N2. L. 46-60.

${ }^{20}$ Cholnoky J. Túrán // Turán. 1918. N 1 (Január). P.25-43; Cholnoky J. A Magyarországi TuránSzövetség. A turáni gondolat és a turáni népek ismertetése - A szövetség célja. Budapest, 1922; Fodor F. A turáni államok jövendő békéjének földrajza I // Turán. 1917. N 8-9 (október - november). Ol. 337-347; Bán A. A Turáni népek // Turán. 1940. N 2. Ol. 57-59; Márki S. A turáni népek jelene és jövője // Turán. 1923. N 1-2. Ol. 1-13.

21 Pusztay J. Az "ugor-török háború" után. Budapest, 1977.

22 Szíj E. A finnugor néprokonsági eszme a 20-as, 30-as években // Östörténet és nemzettudat 19191931 (Magyar Östörténeti Könyvtár 1). Szeged, 1991 / Sz. N.E. Kincses. P.72-88; Szíj E. Pánfinnugor és antifinnugor elméletek, mozgalmak // 125 éves a budapesti finnugor tanszék. Jubileumi kötet (Urálisztikai Tanulmányok 9) / sz. M. Csepregi, P. Domokos. Budapest, 1998. Ol. 145-152.

${ }^{23}$ Fekete L. Türkische Schriften aus dem Archive des Palatins Nikolaus Esterházy, 1606-1645. Budapest, 1932; Szakály F. Szigetvári Csöbör Balázs török miniatúrái 1570. Budapest, 1983; Lengyel B. A török Magyarországon. Magyarország a XVI-XVII. Században. Budapest, 1971; Fehér G. A magyar történelem oszmán-török ábrázolásokban. Budapest, 1982; Fodor P. Magyarország és a török hódítás. Budapest, 1991; Fodor P. In Quest of the Golden Apple. Imperial Ideology, Politics, and Military Administration in the Ottoman Empire. Istanbul, 2000.

${ }^{24}$ Boglárka J. Kelet felé szabadon? A turanizmus nyomában // Körkép. 2016. 16 december. URL: http:// www.korkep.sk/cikkek/tortenelem/2016/12/16/kelet-fele-szabadon-a-turanizmus-nyomaban (accessed 12.02.2017); Varga M. Keleti Nyitás 1.0 - Turanizmus a korabeli Magyarországon // Budapest Science Meetup. 2016. Június $26 \mathrm{URL}$; https://sciencemeetup.444.hu/2016/06/26/keleti-nyitas-10-turanizmus-a-korabeli-magyarorszagon (accessed 12.02.2017); Marcell T. Attól, hogy valaki szereti sushit és a mangát, még nem lesz turanista // Szeged ma. 2017. Február 16. URL: https://szegedma.hu/2017/02/attol-hogy-valaki-szereti-sushit-es-a-mangat-meg-nem-lesz-turanista (accessed 12.02.2017); Varga M. Migrációs kavalkád a vaskori Kárpát-medencében // Budapest Science Meetup. 2017. Január 28. URL: https://sciencemeetup.444. hu/2017/01/28/migracios-kavalkad-a-vaskori-karpat-medenceben (accessed 12.02.2017); Ablonczy B. Keletre, magyar! A magyar turanizmus története. Budapest, 2016.

${ }_{25}$ Ablonczy B. Elmaradt lóáldozat // Magyar Idők. 2016. December 18. URL: https://magyaridok.hu/ lugas/elmaradt-loaldozat-1254205/ (accessed 12.02.2017); Paksa R. A turanizmus gyökerei // Hetek. 2012. Vol.XVI, N 33. 17 augusztus. URL: http://www.hetek.hu/hatter/201208/a_turanizmus_gyokerei (accessed 12.02.2017); Kiss K. Turanizmus: a múltban keressük a kapaszkodókat // Magyar Nemzet. 2017. Február 13. URL: https://elofizetes.mno.hu/tag/turanizmus-126595 (accessed 12.02.2017); Szendrei L. A turanizmus // Debreceni Kossuth Lajos Tudományegyetem Könyvtárának évkönyve. 2008. N 50-29. Ol. 78-125. 
of Turanism actualize the trends of ethnic nationalism in contemporary intellectual discourse. The supporters of political Turanism continue to develop the ideas of their intellectual predecessors ${ }^{26}$ and tend to appeal to the imagined ethnic solidarity, while moderate academic Turanists ${ }^{27}$ recognize the Finno-Ugric roots of modern Hungarian identity and do not reject the fact that the Hungarian language belongs to the Finno-Ugric group. They also try to imagine, invent, and localize the Turkic elements and influences, especially in the early history of the Hungarians, and draw ethnic and linguistic parallels with the Turks. Academic Turanists ${ }^{28}$, in contrast to the political ideologists, do not declare that the Turks were the ethnic and linguistic Hungarian ancestors, but they legitimise and promote collective representations that historic Finno-Ugrian ancestors of the Hungarians were not so passive as nationalists of the 19th century believed but actively participated in the common Ugrian-Turkic political and state history.

Academic Turanism was an attempt to imagine and invent Hungarian identity as collective memory in multiple contexts of intellectual history and invented political and historiographical traditions. Academic Turanism has developed as extremely diverse and heterogeneous intellectual trend and ranges from historical to linguistic and ethnographic studies of ethnically and linguistically related Turkic nations ${ }^{29}$ in the cultural landscapes of modern Hungary. Academic Turanism belongs to the number of the post-modernist cultural and intellectual practices. It has transformed into attempts to place Turanism into Hungarian history of ideas, in particular, and integrate it into the intellectual and political history in general.

Hungarian Turanism as a victim of modernization and progress of the nation-state. Academic Turanism broke up with ideas of romantic nationalism, and it does not legitimise its early political forms but uses Turanist narratives as a source that inspires intellectuals to construct historical memories about attempts of Hungarian intellectuals to cultivate romantic myth of Turanist state and historical continuity. Turanist myth lost

${ }^{26}$ Avar G. Miért veszedelem a turánizmus? // Vigilia. 1935. 1. köt. Ol. 178-186; Balázs G. Nacionalizmus és turanizmus. Gondolatok egy téveszme történetéről // Világosság. 1966. 7. évf. 3. sz. Ol. 162-167; Felvinczi Takács Z. Pánszlávizmus és turánizmus // Nyugat. 1914. 7. évf. Ol. 16-17; Nagy Lajos S. A turánizmus, mint nemzeti és nevelési ideal // Magyar paedagogia. 1915. 24. évf. Ol. 74-75; Namik H. A turanizmus és a faji érzés kialakulása Törökországban // Budapesti szemle. 1927. 55. évf., 205. köt., 595. sz. Ol. 474-478; Szász Z. Turánizmus // Nyugat. 1916. N 16. URL: http://epa.oszk.hu/00000/00022/00204/06304.htm (accessed 12.02.2017).

27 Zimonyi I. A magyarság korai történetének sarokpontjai. Elméletek az újabb irodalom tükrében. Szeged, 2012.

${ }_{28}$ Ablonczy B. Keletre, magyar! A magyar turanizmus története. Budapest, 2016; Szendrei L. A turanizmus: Definíciók és értelmezések 1910-től a II. Világháborúig. Budapest, 2010.

${ }^{29}$ Bakay K. Szempontok a hungarizmus és a turánizmus új értelmezéséhez // Kapu. 2012. 25. évf. 2. sz. Ol. 46-48; Balogh L. A dunai bulgárok keresztény hitre térése: térítés - megtérés. A világvallások terjedése Kelet-Európa népei között // Magyar Östörténeti Könyvtár 25. Budapest, 2009. Ol. 67-77; Berta Á. Török eredetü törzsneveink // Nyelvtudományi Közlemények 92. Budapest, 1991. Ol. 3-40; Farkas I. A magyar turanizmus török kapcsolatai // Valóság. 2007. 50. évf. 6. sz. Ol. 31-48; Farkas I. A turánizmus // Magyar tudomány. 1993. 38 (100). köt. 7. sz. Ol. 860-868.; Oláh P. A török és a magyar turanizmus kapcsolata a 20. század első felében // Keletkutatás. 2012, tavasz. Ol. 67-86; Oláh P. Turanizmus: török-magyar kapcsolódási pontok a XX. század első felében // Valóság. 2011. (54. évf.) 4. sz. Ol. 44-71; Szendrei L. A turanizmus: ön- és negatív definíciók, értelmezések 1910-től a II.// Könyv és könyvtár: könyvtártudományi és bibliográfiai tanulmányok és közlemények: a Debreceni Kossuth Lajos Tudományegyetem Könyvtárának évkönyve. 2007. 29. köt. Ol. 78-125; Zimonyi I. A magyarság korai történetének sarokpontjai. Elméletek az újabb irodalom tükrében. Szeged, 2012; Zimonyi I. A magyarság korai történetének sarokpontjai [Magyar Óstörténeti Könyvtár 28]. Budapest, 2014. 
its potential and charm because it became the victim of marginalization: Hungarian statehood formed other dimensions of legitimation and collective representations about the political and historical continuities. The difficulties of formation of collective historical memory in the eras of national and communist authoritarianisms significantly weakened Turanist narratives because Hungarian intellectuals were forced to integrate memories of terror, repression, suppression, and resistance into collective historical and historiographical canons. Despite the cyclical nature of Turanism and negative historical and cultural dynamics, Turanist political myth in the Hungarian national imagination was stable and succeeded in establishing strong connections with Magyarism.

Various intellectual forms of Turanism coexist with ethnic Magyarism in political Hungarian nationalism. Turanism places other ideological accents, which makes it different from the ethicized Finno-Ugric Magyarism. Despite all these differences, two trends co-existed and continuously co-developed in intellectual Hungarian history of Magyar Királyság in the Habsburg Empire ${ }^{30}$, the interwar Europe ${ }^{31}$, the Sovietized Magyar Népköztársaság ${ }^{32}$ and contemporary Magyarország ${ }^{33}$. The romantic Turanism became another victim of politicization and indoctrination of Hungarian society, which preferred to imagine Turanism as part of the history of national revival, locate it on the peripheries of the historical memory or transform it into a part of the genesis of the national Orientalism. If the ideas of Ugrism became central in the ethnic Hungarian national myth and the idealization of the Finno-Ugric ancestors was addede to the list of ideological virtues of nationalism, Turanism and romantic attempts of Hungarian nationalists to imagine and invent the Turks as the perfect and correct ancestors lost its political and ideological significance and gradually became the first steps in the genesis and the further development of Hungarian Orientalism.

${ }^{30}$ Kunos I. Oszmán-török népköltési gyüjtemény. Budapest, 1887; Kúnos I. Török népmesék. Budapest, 1889; Kunos I. Kisázsia török dialektusairól. Budapest, 1896; Pröhle V. Rendszeres oszmán-török nyelvtan. Pozsony, 1899; Sára P. A magyar nyelv eredetéről másképpen. Budapest, 1994; Sára P. A magyar nyelv titokzatos forrásánál. Rokon vonások, szerkezeti hasonlóságok a Magyar és a Török nyelvekben. Budapest, 1996; Sára P. A magyar-török rokonságról. Budapest, 1995; Szakály F. A magyar jogszolgáltatás és közigazgatás a török hódoltságban I. Budapest, 1997; Thúry J. A közép-ázsiai török irodalom. Budapest, 1907; Thúry J. A közép-ázsiai török nyelv ismertetései. Budapest, 1906.

31 Cholnoky J. A belső-ázsiai puszták // Turán. A Turáni Társaság (Magyar Néprokonsági Egyesület). 1936. Vol. I-IV. Ol. 23-29; Fekete L. A törökkori Vác egy XVI. századi összeírás alapján. Budapest, 1942; Fekete L. Török birtokrendszer a hódolt Magyarországon. Budapest, 1940; Lukinich F. A néprokonsági eszme terjesztése // Turán. A Turáni Társaság (Magyar Néprokonsági Egyesület). 1936. Vol. I-IV. Ol. 53-57; Paikert A. A turáni népek világhivatása // Turán. A Turáni Társaság (Magyar Néprokonsági Egyesület). 1936. Vol. I-IV. Ol. 19-22; Wigand E. Turáni öreg csillagok // Turán. A Turáni Társaság (Magyar Néprokonsági Egyesület). 1936. Vol. I-IV. Ol. 57-64.

32 Bidzsári H. A török irodalom. Budapest, 1973; Fekete L. Budai török számadáskönyvek (15501580). Budapest, 1962; Fekete L. Budapest története a török korban. Budapest, 1974; Gerö G. Buda török műemlékei. Budapest, 1957; Gerő G. Pécs török műemlékei. Budapest, 1960; Gerő G. Pécs törökkori emlékei. Budapest, 1962; Gerő G. Török építészeti emlékek Magyarországon. Budapest, 1976; Molnár J. A török világ emlékei Magyarországo. Budapest: Corvina Kiadó, 1976; Nagy L. A török világ végnapjai Magyarországon. Budapest: Zrínyi Katonai Könyv- és Lapkiadó, 1986; Soproni O. A magyar művészi kerámia születése. Budapest, 1977; Szabó P., Rúzsás L. A török Pécs. Pécs, 1958; Szakály F. A török félhold árnyékában. Budapest, 1988.

${ }^{33}$ Fekete L. A hódoltság török levéltári forrásai nyomában. Budapest, 1993; Fodor P. “Az ország ügye mindenek előtt való”. A szultáni tanács Magyarországra vonatkozó rendeletei (1544-1545, 1552). Budapest, 2005; Fodor P. A szultán és az aranyalma. Tanulmányok az oszmán-török. Budapest, 2001; Fodor P. Vállalkozásra kényszerítve. Az oszmán pénzügyigazgatás és hatalmi elit változásai a 16-17. század. Budapest, 2006. 
It is extremely difficult to determine what motives and ideas stimulated Hungarian intellectuals to cultivate and promote the idea of Turkish-Hungarian continuities because the linguistic identity of the Hungarian nation in the $19^{\text {th }}$ century, when these ideas arose, was not Turkish, but developed as a Finno-Ugric because the language and ethnicity defined the main vectors and trajectories in developments and transformations of Hungarian nationalism. German intellectual influences, in particular, and Western intellectual stimuli, in general, inspired the progress of Hungarian Turanism, but it would be logical to assume that the wrong linguistic and ethnic speculations of European authors and real political influences of the Ottoman Empire spurred the interests of Hungarian authors in hypothetical Turkic roots of the nation they belonged to. Magyar Királyság or the Hungarian Kingdom was part of the multinational and heterogeneous Habsburg Empire in the $19^{\text {th }}$ century when the Ottoman Empire was among formally influential European empires.

The crisis of the Ottoman Empire and the inability of its elites to prevent, stop and slow the processes of decay and increase in separatist movements could not weaken the reputation and influence of the romantic legends about the Ottoman state and its political myth. The Ottoman Empire was not very interesting for the rational Hungarian nationalists because Turanism as a factor of the probable and possible political mobilization and public legitimation attracted them incomparably more than romantic nationalist aspirations. Ugrism actualized the ethnic components in the ideology of Hungarian nationalism, but it obviously was weaker than Turanism because independent Finno-Ugric states did not exist in the $19^{\text {th }}$ century and relative communities were not nations and existed as the oppressed minorities in the Russian Empire.

Hungarian nationalism developed as a political state and romantic ethnic ideology that sought to protect and defend the special rights and privileges of Hungary in the Habsburg Empire. Hungarian ethnic nationalism mutated into other nationalistic forms used for the state legitimation and their political aspirations. Turanism ceased to be a nationalist strategy that actualizes the state narratives in the ideology of Hungarian nationalism because Turanist trends, on the one hand, transformed into political invented tradition. On the other hand, intellectual Turanism became the victim of fragmentation: academicized forms of Turanism, such as historical, cultural and linguistic studies of Turkic nations coexist with pseudo-academic theories of folk historical style. Hungarian nationalists who rejected Magyarism in its Finno-Ugric forms preferred to absolutize and idealize Turkic-Hungarian parallels and participated in the international activities of the pan-Turkic organizations. Turanism became a form of instrumentalization and the articulation of non-academic and romantic speculations and attempts to connect romantic ideas of ethnic nationalism with political messages of Hungarian elites. Theorists of ethnic nationalism sought to legitimise political ambitions and prove the continuity between the different national traditions of Hungarians and their imagined Turkic ancestors simultaneously by including Turanism as the private case of the theory of Turkic-Hungarian continuity.

Political elites sought a symbolic legitimation of power, married the history, but the dynamic changes of regimes left history a widow three times and inspired historians to change the epistemological paradigms and dominant approaches to historical imagination in the second half of the $20^{\text {th }}$ century. The absence of real historical and political continuities stimulated developments of myths of state and continuity in its symbiosis with nationalism. Nationalist imagination transplanted the ethnicised modern nation in the 
past and provided a medieval state with the necessary ethnic characteristics. Nationalists replaced the collective traumas of political failures and the inevitable historical defeats and lacunas with the myth of state continuity.

Ethnic is too political, or why political narratives prevail over ethnic ones in nationalism. The history of European nationalisms provides historians with numerous examples and attempts to ethnicise and nationalise the past, the active use of history for political needs. The tactics and strategies of the nationalists in their permanent desires and aspirations to glorify nation and use history as the form of political legitimation were varied. Some Hungarian nationalists insisted that the Hungarians were not Ugro-Finns but had Turkic ancestors. These nationalist strategies and tactics of manipulations with history have a lot in common, but their genesis was extremely varied and depended on the local and regional conditions. Hungarian attempts and desires to imagine and invent the Turks as the ancestors have some common features because nationalists projected modern identities and ethnicities in the ethnic group that belonged to other communities. The Finno-Ugric character of the Hungarian language did not prevent the nationalists from arguing that the Hungarians were the direct descendants of Turks despite the fact that the Finno-Ugric and Turkic languages belong to different language families. The attempts to export modern identities and ethnicities to the past, desires to prove and actualize ethnic and partly political successions had different reasons and incentives in Hungarian nationalism. Despite the fact that Hungary had a significant and visible political rights and institutions in the Habsburg Empire, Hungarian nationalists believed that political nationalism was not enough for the modernization and successful transformation of peasants into a nation. Nationalists faced a deficit of historical and political legitimacy that stimulated their attempts to imagine Turks as the ideal state and historical ancestors, as well as ethnicize them and find common Hungarian-Turkic elements in history. The synthesis of ethnic Magyarized national canon with Turkic myth actualized new dimensions of Hungarian political identity: the nationalists, on the one hand, were true believers and adepts of values of the nation and ethnic nationalism; on the other hand, they had a political sense of of their nation's belonging to the Turkic world. The nationalists imagined Turkic world as a more politically successful because the Ottoman Empire in the $19^{\text {th }}$ century was a significant factor in European politics, and the Finno-Ugric groups were virtually invisible, unobtrusive, and oppressed minorities. This complex of political inferiority does not stop Hungarian nationalists from oppressing the Slavic groups and ignoring their rights in the Habsburg Empire. Turkic myths in Hungarian nationalism combined ethnic and political nationalist ambitions. These myths had instrumentalist roles, and nationalists actively used them for political mobilization, transformation of traditional communities in the nations. These myths became the inventions of romantic nationalists, but rational pragmatic nationalists used their results and achievements for implementation and further progress of national identities. The speculative ideas about Turkish ethnic roots were interesting for the political nationalists because the results of possible political and instrumentalist use of these myths and romantic slogans inspired speculations with history and also legitimised nationalist successes. It is logical to presume that nationalists understood the fragility and non-academic nature of their ideas and concepts, but the political potential of these myths was more attractive than the norms of academic ethics.

Preliminary conclusions. The relationships between nationalism and history are extremely complex and contradictory. They intensified in the rapid process of nationalizing, 
politicizing and liberalizing of nations, ambitious in their attempts to invent the nation and provide it with political and national identities. The history will inevitably become hostage to the political and ideological conditions in this intellectual situation and nationalists will actively use facts of the past in their attempts to legitimize political objectives, intentions and actions. The perceptions of historical facts and political practices of nationalists and academic historians are extremely diverse. Nationalists are interested in history as political and ideological instrument in their struggle for the rights and freedoms of the nation they belong to, or the nation they imagine and invent. Political preferences of nationalism determine the trajectories of development of the history in dynamically nationalizing societies. The invention of great historical ancestors, who provide modern nation-states with historical and political precursors, is one of the strategies nationalists actively used to form, strengthen and promote national identity. The nationalist speculations and manipulations contribute to the transformations of history in one of the invented traditions, including political rituals, secular and civil ceremonies, military parades, coronations or inaugurations. History becomes indispensable in situations when nationalizing societies face a deficit of political legitimacy and historical memory. Nationalists, on the one hand, radically solve this problem and invent new legitimacies and histories, which have never before existed. Nationalists also provide chronologically distant communities and groups of the past with modern ethnicities and identities. On the other hand, the nationalist-minded intellectuals radically, decisively and consistently may deny the historical roles and significances of other ethnic groups and their states in the history of the nation they belong to. The historiographical fates of ancient Turkic tribes exemplify how nationalists use and nationalize history and provide different group with politically necessary identities. These manipulations with history transform it into the imagined and invented traditions. The contemporary intellectual situation is more heterogeneous, and attempts to revive the idea of the identity and direct continuity co-exist with academic attempts to prove that the Turks were important historical actors in the contexts of political history because they had their own state that was at the same time ethnically heterogeneous and also among the historical antecedents of Hungarian statehood. Despite the formal heterogeneity, nationalist tactics and strategies of historical imaginations, the invention of histories, the historical manipulations and speculations have a lot in common. The development and progress of the state institutions weaken ethnic nationalism, marginalize the ethnicized historical concepts, replace them and expel into the social and cultural peripheries of the non-academic historiographies. The non-academic and academized forms of Hungarian nationalism coexist in contemporary historiographies. Academic and non-academic historians will use a variety of tactics and strategies for development and further promotion of these myths. The intellectual spaces and communities will continue to exist as a fragmented and heterogeneous groups. Intellectuals will play the roles of nationalists, nationalists will disguise as intellectuals, and they will collectively and occasionally revive old ghosts of political and historiographical national and class myths with their idols of great political ancestors and predecessors.

\section{References}

Ablonczy B. "Lándzsahegy", néprokonság, small talk: Turanizmus és keleti gondolat a két világháború közötti magyar külpolitikai gondolkodásban. Magyar külpolitikai gondolkodás a 20. században (A VI. Hungarológiai Kongresszus, Debrecen, 2006. augusztus 22-26, szimpóziumának anyaga). Sz. P. Pritz, B. Sipos, M.Zeidler. Budapest, Magyar Történelmi Társulat, 2006, ol. 60-73. 
Ablonczy B. Keletre, magyar! A magyar turanizmus története. Budapest, Jaffa Kiadó, 2016, 296 ol.

Aibert B. N. Macaristan'in Turanilikteki Rolü, Türk Yurdu, 1914, vol. VI, no. 4 (April), ol. 270-274.

Akçura Y. Türkçülük. Türk Yili. Istanbul, Yeni Matbaa Publ., 1928, ol. 287-455.

Arany J. Haraszti, Gyula, 1858-1921. Budapest, Athenaeum Publ., 1912, $124 \mathrm{ol}$.

Arany J. Válogatott balladái. Budapest, Lampel Róbert Publ., 1917, 174 ol.

Arnakis G. Turanism: An Aspect of Turkish Nationalism, Balkan Studies, 1960, vol. 1, no. 1, pp. 19-32.

Avar G. Miért veszedelem a turánizmus? Vigilia. 1935. 1. köt., ol. 178-186.

Bakay K. Szempontok a hungarizmus és a turánizmus új értelmezéséhez. Kapu, 2012. 25. évf. 2. sz., ol. $46-48$.

Balázs G. Nacionalizmus és turanizmus. Gondolatok egy téveszme történetéröl. Világosság, 1966. 7. évf. 3. sz., ol. 162-167.

Balogh L. A dunai bulgárok keresztény hitre térése: térítés - megtérés. A világvallások terjedése Kelet-Európa népei között. Magyar Östörténeti Könyvtár 25. Sz. L. Balogh, Sz. Kovács Budapest, Balassi Kiadó Publ., 2009, ol. 67-77.

Bán A. A Turáni népek. Turán, 1940, no. 2, pp. 57-59.

Berta Á. Török eredetű törzsneveink. Nyelvtudományi Közlemények 92. Budapest, MTANI Press, 1991, ol. 3-40.

Bidzsári H. A török irodalom. Budapest, Tankönyvkiadó Vállalat Publ., 1973, 342 ol.

Cholnoky J. A belső-ázsiai puszták. Turán. A Turáni Társaság (Magyar Néprokonsági Egyesület). 1936, vol. I-IV, ol. 23-29.

Cholnoky J. A Magyarországi Turán-Szövetség. A turáni gondolat és a turáni népek ismertetése - A szövetség célja. Budapest, A Magyarországi Turán-szövetség kiadása Publ., 1922, 128 ol.

Cholnoky J. Túrán. Turán, 1918, no. 1 (Január), ol. 25-43.

Demirkan T. Macar Turancilari. Istanbul, Tarih Vakfi Yurt Yayinlari Publ., 2000, 158 ol.

Duka Th. Life and works of Alexander Csoma de Körös: a Biography Compiled Chiefly from Hitherto Unpublished Data. With a Brief Notice of Each of his Unpublished Works and Essays, as Well as of his Still Extant Manuscripts. London, Trübner, 1885, $234 \mathrm{ol}$.

Farkas I. A magyar turanizmus török kapcsolatai. Valóság, 2007. 50. évf. 6. sz., ol. 31-48.

Farkas I. A turánizmus. Magyar tudomány, 1993. 38. (100.) köt. 7. sz, ol. 860-868.

Fehér G. A magyar történelem oszmán-török. Budapest, Akadémiai Kiadó Publ., 1982, 250 ol.

Fekete L. A hódoltság török levéltári forrásai nyomában. Budapest, Magyar Tudományos Akadémia Könyvtára Publ., 1993, 489 ol.

Fekete L. A törökkori Vác egy XVI. századi összeírás alapján. Budapest, Magyar Tudományos Akadémia Publ., 1942, $364 \mathrm{ol}$.

Fekete L. Budai török számadáskönyvek (1550-1580). Budapest, Akadémiai Publ., 1962, 210 ol.

Fekete L. Budapest története a török korban. Budapest, Akadémiai Publ., 1974, $112 \mathrm{ol}$.

Fekete L. Török birtokrendszer a hódolt Magyarországon. Budapest, Magyar Tudományos Akadémia Publ., 1940, 128 ol.

Fekete L. Türkische Schriften aus dem Archive des Palatins Nikolaus Esterházy, 1606-1645. Budapest, Universitätsdruck Press, 1932, $501 \mathrm{~s}$.

Felvinczi Takács Z. Pánszlávizmus és turánizmus. Nyugat, 1914. 7. évf, ol. 16-17.

Fodor F. A turáni államok jövendő békéjének földrajza I. Turán, 1917, no. 8-9 (Október - November), ol. 337-347.

Fodor F. A turáni államok jövendő békéjének földrajza II. Turán, 1917, no. 10 (December), ol. 447-459.

Fodor P. "Az ország ügye mindenek elött való". A szultáni tanács Magyarországra vonatkozó rendeletei (15441545, 1552). Budapest, MTA Történettudományi Intézete Press, 2005, 757 ol.

Fodor P. A szultán és az aranyalma. Tanulmányok az oszmán-török történelemröl. Budapest, Balassi Kiadó Publ., 2001, 408 ol.

Fodor P. In Quest of the Golden Apple. Imperial Ideology, Politics, and Military Administration in the Ottoman Empire. Istanbul, Isis, 2000, 304 p.

Fodor P. Magyarország és a török hódítás. Budapest, Argumentum Publ., 1991, 269 ol.

Fodor P. Vállalkozásra kényszeritve. Az oszmán pénzügyigazgatás és hatalmi elit változásai a 16-17. század fordulóján. Budapest, MTA Történettudományi Intézete - Magyar-Török Baráti Társaság Press, 2006, $371 \mathrm{ol}$.

Gerő G. Buda török müemlékei. Budapest, Képzőművészeti Alap Kiadóvállalata Publ., 1957, 54 ol.

Gerő G. Pécs török müemlékei. Budapest, Képzőművészeti Alap Kiadóvállalata Publ., 1960, 48 ol.

Gerő G. Pécs törökkori emlékei. Budapest, Közlekedési Dokumentációs V Publ., 1962, 92 ol.

Gerő G. Török építészeti emlékek Magyarországon. Budapest, Corvina Kiadó Publ., 1976, 86 ol. 
Huszka J. A magyar turáni ornamentika története. Budapest, Nyers Csaba Publ., 1996, 178 ol.

Kessler J. Turanism and Pan-Turanism in Hungary, 1890-1945. Berkeley, University of California, Ann Arbor, University Microfilms Inc., 1967, 605 p.

Kiss A. Magyar Kelet-politika a rokonság jegyében - az östörténet, mint társadalom- és gazdaságpolitikai tényezö 100 éve és ma. Budapest, Kiss Attila Publ., 2015, 63 ol.

Kunos I. Oszmán-török népköltési gyüjtemény. Budapest, Magyar Tudományos Akadémia Publ., 1887, $465 \mathrm{ol}$.

Kúnos I. Török népmesék. Budapest, Kisfaludy Társaság, 1889, 224 ol.

Kunos I. Kisázsia török dialektusairól. Budapest, Magyar Tudományos Akadémia Publ., 1896, 46 ol.

Le Calloch' B. Alexandre Csoma de Körös. Revue de l'histoire des religions, 1985, no. 4, p. 353-388.

Lengyel B. A török Magyarországon. Magyarország a XVI-XVII. Században. Budapest, Móra Ferenc Ifjúsági Könyvkiadó Publ., 1971, 268 ol.

Lukinich F. A néprokonsági eszme terjesztése. Turán. A Turáni Társaság (Magyar Néprokonsági Egyesület), 1936, vol. I-IV, ol. 53-57.

Márki S. A turáni népek jelene és jövője. Turán, 1923, no. 1-2, ol. 1-13.

Molnár J. A török világ emlékei Magyarországo. Budapest, Corvina Kiadó Publ., 1976, 126 ol.

Mukerjee H. Hermit-hero from Hungary, Alexander Csoma de Koros, the Great Tibetologist. New Delhi, Light \& Life Publishers, 1981, $102 \mathrm{p}$.

Müller Fr. The Languages of the Seat of War in the East. With a Survey of the Three Families of Language, Semitic, Arian and Turanian. London, Williams and Norgate, 1855, $267 \mathrm{p}$.

Nagy L. A török világ végnapjai Magyarországon. Budapest, Zrínyi Katonai Könyv- és Lapkiadó Publ., 1986, $412 \mathrm{ol}$.

Nagy Lajos S. A turánizmus, mint nemzeti és nevelési ideal. Magyar paedagogia, 1915, 24. évf., ol. 74-75.

Namik H. A turanizmus és a faji érzés kialakulása Törökországban. Budapesti szemle, 1927. 55. évf., 205. köt., 595. sz., ol. 474-478.

Oguz A. The Interplay between Turkish and Hungarian Nationalism: Ottoman Pan-Turkism and Hungarian Turanism (1890-1918). A Thesis Submitted to the Graduate School of Social Sciences of the Middle East Technical University. Middle East Technical University, 2005, 146 p.

Oláh P. A török és a magyar turanizmus kapcsolata a 20. század első felében. Keletkutatás, 2012, tavasz, ol. 67-86.

Oláh P. Turanizmus: török-magyar kapcsolódási pontok a XX. század első felében. Valóság, 2011, (54. évf.) 4. sz., ol. 44-71.

Önen N. Turanci hareketler: Macaristan ve Türkiye (1910-1944). Doktora tezi. Ankara, Ankara Üniversitesi Sosyal Bilimler Enstitüsü Kamu Yönetimi ve Siyaset Bilimi Press, 2003, 497 s.

Paikert A. A turáni népek világhivatása. Turán. A Turáni Társaság (Magyar Néprokonsági Egyesület), 1936, vol. I-IV, ol. 19-22.

Pröhle V. Napkeletröl. Budapest, Stádium Sajtóvállalat Rt. Publ., 1922, 356 ol.

Pröhle V. Rendszeres oszmán-török nyelvtan. Pozsony, Stampfel Károly Publ., 1899, 96 ol.

Pulszky F. Magyarország archaeologiája II. Budapest, Históriaantik Könyvesház Publ., 2010, 570 ol.

Pusztay J. Az "ugor-török háború" után. Budapest, Magvető Könyvkiadó Publ., 1977, 184 ol.

Sándor M. Az ó- és középkor története. Budapest, KAINR Publ., 1910, $700 \mathrm{ol}$.

Sára P. A magyar nyelv eredetéról másképpen. Budapest, Arculat Publ., 1994, 196 ol.

Sára P. A magyar nyelv titokzatos forrásánál. Rokon vonások, szerkezeti hasonlóságok a Magyar és a Török nyelvekben. Budapest, Szenci Molnár Társaság Publ., 1996, 420 ol.

Sára P. A magyar-török rokonságról. Budapest, Püski Kiadó Kft Publ., 1995, 261 ol.

Schmidt J. Turánizmus. Nyugat [West], 1925, no. 20, ol. 137-200.

Sebestyén G. A magyar rovásirás hiteles emlékei. Budapest, Magyar Tudományos Akadémia Press, 1915, $218 \mathrm{ol}$.

Sööt K. Észt-magyar művészek rokonbarátsági érintkezése. Turán, 1932, no. 1-4, ol. 15-17.

Soproni O. A magyar müvészi kerámia születése. Budapest, Népmüvelési Propaganda Iroda Publ., 1977, $241 \mathrm{ol}$.

Szabó P., Rúzsás L. A török Pécs. Pécs, MJ. Város Tanácsa VB. Művelődésügyi Osztály Publ., 1958, 105 ol.

Szakály F. A magyar jogszolgáltatás és közigazgatás a török hódoltságban I. Budapest, MTA Történettudományi Intézet Press, 1997, 418 ol.

Szakály F. A török félhold árnyékában. Budapest, Reflektor Kiadó Publ., 1988, 63 ol.

Szakály F. Szigetvári Csöbör Balázs török miniatúrái 1570. Budapest, Európa Könyvkiadó Publ., 1983, 76 ol.

Szendrei L. A turanizmus. Debreceni Kossuth Lajos Tudományegyetem Könyvtárának évkönyve, 2008, no. 50-29, ol. 78-125. 
Szendrei L. A turanizmus: Definíciók és értelmezések 1910-töl a II. Világháborúig. Budapest, Attraktor Könyvkiadó Kft. Publ., 2010, 157 ol.

Szendrei L. A turanizmus: ön- és negatív definíciók, értelmezések 1910-től a II. Világháborúig. Könyv és könyvtár: könyvtártudományi és bibliográfiai tanulmányok és közlemények: a Debreceni Kossuth Lajos Tudományegyetem Könyvtárának, 2007, 29. köt., ol. 78-125.

Szíj E. A finnugor néprokonsági eszme a 20-as, 30-as években. Östörténet és nemzettudat 1919-1931 (Magyar Östörténeti Könyvtár 1). Sz. N. E. Kincses. Szeged, Balassi Kiadó Publ., 1991, ol. 72-88.

Szíj E. Pánfinnugor és antifinnugor elméletek, mozgalmak. 125 éves a budapesti finnugor tanszék. Jubileumi kötet (Urálisztikai Tanulmányok 9). Sz. M. Csepregi, P. Domokos. Budapest, ELTE Finnugor Tanszék, 1998, ol. 145-152.

The invention of tradition / eds E. Hobsbawm, T. Ranger. Cambridge, Cambridge University Press, 1983. $320 \mathrm{p}$.

Thúry J. A közép-ázsiai török irodalom. Budapest, Magyar Tudományos Akadémia Press, 1907, 77 ol.

Thúry J. A közép-ázsiai török nyelv ismertetései. Budapest, Magyar Tudományos Akadémia, 1906, 37 ol.

Vaas Th. Hõimuküsimus ja turanism. Üliõpilasleht, 1925, no. 6, ol. 127-128.

Vámbéry Á. A keleti török nyelvröl. Pest, Eggenberger, 1868, 18 ol.

Vámbéry Á. Közép-ázsiai utazás. Pest, Emich Gustav Tulajdina, 1865, 26 ol.

Vámbéry Á. Küzdelmeim. Budapest, Franklin-Társulat Magyar Irod. Intézet És Könyvnyomda, 1905, 96 ol.

Virányi E. A finn-ugor néprokonság eszméje az irodalomban. Turán, 1935, no. 1-4, ol. 15-21.

Virányi E. Kultuurajaloolised kokkupuuted Eesti ja Ungari vahel. Eesti Hõim, 1928, no. 2, ol. 97-109.

Wigand E. Turáni öreg csillagok. Turán. A Turáni Társaság (Magyar Néprokonsági Egyesület), 1936, vol. I-IV, ol. 57-64.

Wilde E. Muljed Ungarist ja ungarlasist. Eesti Hõim, 1928, no. 2, ol. 46-60.

Zimonyi I. A magyarság korai történetének sarokpontjai [Magyar Östörténeti Könyvtár 28]. Budapest, Balassi Kiadó, 2014, 252 ol.

Zimonyi I. A magyarság korai történetének sarokpontjai. Elméletek az újabb irodalom tükrében. Szeged, 2012, $278 \mathrm{ol}$. 